\section{Dzyuba N., Bunyak 0., Telezhenko L., Oliinyk $\mathbf{M}$.}

\title{
MATHEMATICAL DESIGN OF BLANGANGE RECIPES FOR HORECA SPHERE AND DETERMINATION OF THEIR OUALITY INDICATORS
}

The object of research is a composition of aerated dessert with a balanced nutritional composition for nutrition of people suffering from hypolactasia. The article describes the mathematical and computer design to obtain recipe compositions of desserts, namely blancmange «Fruit Breeze» and «Protein Breeze» with high content of vitamins and protein. When designing blancmange recipes, the main goal was to obtain the maximum value of the product with the following content of nutrients (per $100 \mathrm{~g}$ of finished product):

- fat - not more than $11 \%$;

- monocarbohydrates - not more than $65 \%$ and not less than $50 \%$;

- dry matter - not more than $85 \%$ and not less than $96 \%$;

- proteins - not less than $20 \%$.

Optimization of blancmange formulations was performed using the Excel Solver of the MS Excel spreadsheet (WINDOWS 2010). The content of basic macronutrients in a portion of «Fruit Breeze» is $69.77 \mathrm{~g} /$ portion, in a portion of «Protein Breeze» $-78.55 \mathrm{~g} /$ portion. The developed products have a high content of protein, and they do not contain lactose, which is important in terms of meeting the needs of the human organism with hypolactasia.

The change of sensory and microbiological parameters of the developed desserts during storage for 5 days at a temperature of $(4 \pm 2){ }^{\circ} \mathrm{C}$ with a humidity of $70-85 \%$ in glass and polypropylene containers was determined. The obtained data of the study of qualitative indicators showed that under certain storage conditions, the content of sanitary-indicatory microorganisms meets the sanitary requirements for sweet dishes. Sensory indicators during storage showed high values. Thus, the total sensory indicator after 5 days of storage for «Fruit Breeze» was 29.5 points, and «Protein Breeze» was 31.7 points out of 35 possible.

Developed desserts can be recommended for use by people with hypolactasia, children, in the dietary nutrition.

Keywords: mathematical modeling of recipe, sweet dishes, nutrition of people suffering from hypolactasia.

Received date: 03.08 .2020

Accepted date: 17.09 .2020

Published date: 31.12 .2020
Copyright (C) 2020, Dzyuba N., Bunyak O., Telezhenko L., Oliinyk M. This is an open access article under the CC BY license (http://creativecommons.org/licenses/by/4.0)

\section{Introduction}

One of the promising areas of research in the field of healthy eating is the development of the food industry focused on the production of healthy foods - low-calorie, high in vitamins, minerals, polyunsaturated fatty acids (PUFA) and more. Particular attention is paid to the creation of products that have antiallergenic, anti-stress, adaptogenic, tonic, stimulating and radioprotective properties.

It should be noted that the number of consumers who choose a vegetarian lifestyle and do not eat animal products is growing every year. This is due to the desire to avoid the now common «diseases of civilization», such as atherosclerosis, hypertension, allergies, various tumors, as well as premature aging.

Increasing the number of people suffering from allergies or hypersensitivity to animal proteins, as well as unable to digest milk sugar (lactose), stimulates the development of new generation products based on the use of vegetable raw materials as a source of protein and proteinfatty products. Special attention needs to be paid to the organization of nutrition of people suffering from allergies to dairy products, as well as to such an inherited disease as hypolactasia, rather the inability of the organism to absorb milk sugar - lactose.

\section{The object of research and its technological audit}

The object of research is a composition of aerated dessert with a balanced nutritional composition for nutrition of people suffering from hypolactasia.

Blancmange is a French dairy dessert with a jelly structure. Milk of both animal and vegetable origin is used for its production, gelatin is usually added as a gelling component.

The following raw materials were used for the study: - almond kernels (DSTU UNECE DDF-06:2007. Almond kernels. Guidelines for supply and quality control); - dried sunflower fruits (DSTU 8494:2015. Dried sunflower fruits. Specifications);

- cocoa powder (DSTU 4391:2017. Cocoa powder. General specifications);

- fresh blueberries (DSTU 691:2004. Fresh blueberries. Specifications); 
- cashew kernels (DSTU ISO 6477:2019. Cashew kernels. Specifications (ISO 6477:1988, IDT));

- soy yogurt (DSTU 4343:2004. Yogurts. General specifications);

- coconut oil (DSTU 4562:2006);

- fresh mango (ISO 6660:1993, IDT. Mango. Cold storage);

- vanilla sugar (DSTU 1009:2005. Vanilla sugar. Specifications);

- coconut shavings (TU 10.39.23-003-49073982);

- collagen hydrolyzate [1].

One of the problems is the development of a prescription composition of a dessert with a balanced nutrient composition that does not contain lactose and can be recommended for use by people suffering from hypolactose.

\section{The aim and objectives of research}

The aim of research is the mathematical design of a multicomponent blancmange composition for people with hypolactosis.

To achieve this aim, the following objectives were set:

1. To carry out mathematical and computer design of blancmange recipes for people with hypolactosis.

2. To determine the conditions and terms of storage of the received blancmange according to change of their sensory and microbiological indicators.

3. To determine the nutrient composition of the obtained blancmange.

\section{Research of existing solutions of the problem}

Approximately $15 \%$ of people in Europe report on lactose intolerance, the Latin Americans have lactose intolerance up to $80 \%$ and the Chinese have almost $100 \%$ [2]. People with lactose intolerance are unable to fully digest it, which leads to the accumulation of lactose in the small intestine, which affects intestinal disorders [3]. However, the effect of accumulated lactose on cellular aging remains largely unknown.

An important direction in the food industry is the search for promising vegetable raw materials and the creation of new food products for the dessert group. Recently, organic products have become increasingly popular - without the addition of sugar, hormones, antibiotics, growth stimulants and more. Dining outlets try to introduce such products into the diet, because when they are consumed, the human organism receives various vitamins and minerals it needs.

Desserts are a group of foods in a wide range, which differ significantly in composition and consumer characteristics. They are in constant demand primarily due to their exquisite taste. Consumption of desserts plays a significant role in the proper nutrition of different age groups, especially children.

Foaming agents of various natures are widely used in modern dining outlets, which form the rheological properties of the finished product and determine its sensory parameters. Due to their high cost, in recent years more and more attention is paid to the search for new stabilizers for cooking with an aerated structure, which improves the nutritional and biological value of products.

A sour-milk frozen dessert based on soy milk has been developed [4]. The use of Lactobacillusparacasei in fer- mented and unfermented frozen soy dessert was determined, and the physicochemical, rheological and sensory properties of the obtained products were evaluated. The sensory properties of fermented probiotic frozen soy dessert were significantly improved by fermentation. However, the authors investigated only one species of lactic acid bacteria of the Lactobacillusgenus, which does not fully predict the fermentation of soy milk using other lactic acid bacteria or their consortium.

To obtain a stable foam structure of frozen desserts used vegetable fats of varying degrees of saturation [5]. Stability in terms of aeration characteristics was measured by quantifying the size distribution of fat globules, melting resistance and heat shock resistance. But in the study it is unclear how the authors justify the choice concentration of vegetable fats.

As non-dairy desserts, fruit gels have been developed, which are recommended in the heroic diet [6]. Banana gels are recommended as an alternative to foods that provide the necessary nutrition for the elderly persons with dysphagia. Various hydrocolloids of plant origin were used to provide the required structure. The nutrient composition of the products was not taken into account when making up of the gel recipes, only rheological indicators were the main indicator.

The use of protein from legume seeds as an alternative to animal protein in the production of desserts has been studied [7]. Isolates of lupine, pea and soy protein were used in combination with $\kappa$-carrageenan, gellan and xanthan gum to obtain a synergistic effect. Rheological studies have shown that mixed protein-polysaccharide systems with plant proteins and $\kappa$-Carrageenan or gellan gum were good systems for the development of plant-based desserts. However, the study identified only a change in the rheological index - the strength of the gel and did not take into account a comprehensive indicator of the quality of desserts, based on both rheological and sensory indicators.

Stevia extract was used to produce whipped dessert based on cottage cheese [8]. Gelatin is used as a structuring agent, and table salt is used to enhance the sweet taste. But the mentioned above recipe was not optimized for the content of basic nutrients, the authors used as an optimal criterion only sensory indicators.

The known food additive «Magne to food» [9] in the form of nanopowder, which was used as an improver in the structure of whipped desserts. Due to the content of $\mathrm{Fe}^{+2}$ the additive has a wide range of rheological properties. The foaming ability in the production of desserts increases by $(40 \pm 2) \%$ for mousses and almost $55 \%$ for fruit and egg jelly. However, this study does not reveal the effect of the additive on the commercial indicators of finished products during storage, which is an important indicator for products, which are sold in dining outlets.

The physicochemical properties of different types of chocolate ganache from whipped cream, milk, vegetable cream and coconut milk have been studied [10]. The control group was considered ganache with whipped chocolate cream. Ganache with whipped cream with the lowest humidity and highest fat content showed the same result (lowest moisture content and highest fat content; $p<0.05$ ) and resulted in medium hardness. Ganache of vegetable cream and chocolate showed results similar to the results of the mentioned above whipped cream, except for the category of hardness. In general, whipped cream ganache was the 
most popular chocolate in the sensory analysis, but coconut milk chocolate was the softest chocolate among cream substitutes. Due to its low caloric content and softness, coconut milk was considered suitable for making chocolate ganache.

Heated soluble complexes of whey protein isolate with polysaccharides can be used to modify the properties of aerated milk gels, which can be introduced into new textured high-protein desserts [11]. Three polysaccharides with different degrees of density were selected: low-methoxyl pectin, high-methoxyl type D pectin and guar gum. Heated complexes were prepared by heating mixed dispersions $(8 \%$ of protein, $0-1 \%$ of polysaccharide) at $\mathrm{pH}=7$. The foam was introduced into the gel in the form of glucono- $\delta$-lactone, acidified to the final $\mathrm{pH}=4.5$. The excess of aerated gel decreased (up to $73 \%$ ) as the concentration of polysaccharides increased from 0.105 to $0.315 \%$ due to the increased viscosity, which limited the introduction of air. There is a negative relationship between the percentage of drainage and the viscosity of the dispersion.

Thus, the direction of a complex approach to the development of recipes for whipped desserts, taking into account the composition and interaction of basic nutrients is relevant. Expanding the range of cold lactose-free desserts will reduce the level of protein deficiency, enrich the diet with essential vitamins, macro-and micronutrients, dietary fibers and other biologically active substances.

\section{Methods of research}

The process of combining components was based on a priori analysis of information base data on their chemical composition and the calculated degree of balance obtained in modeling variants of prescription mixtures [12]. The implementation of mathematical design of recipes was carried out according to a set of mathematical equations in the editor MS Excel 2010 according to the method described in [12].

The main indicators of the quality of ready-made blancmange were sensory and microbiological indicators. The prepared blancmange were divided into samples weighing $100 \mathrm{~g}$, which were stored in glass and polypropylene containers at a temperature of $(4 \pm 2){ }^{\circ} \mathrm{C}$, at a relative humidity of 75-85\% for 5 days. Sensory analysis was performed by profiling using the developed scale in accordance with DSTU ISO 8589:2013. Sensory research. General guidelines for the design of test rooms (ISO 8589:2007, IDT). Organoleptic evaluation was conducted by a tasting commission, which included a teaching staff of 15 people.

To predict the actual shelf-life of blancmange the presence of major pathogenic bacteria and microorganisms were determined. Microbiological indicators were determined:

- MAFAnM - according to GOST 10444.15;

- Escherichia colibacteria - according to DSTU GOST 30726-2002. Food products. Methods for detecting and determining the number of bacteria of the Escherichiacolispecies (GOST 30726-2001, IDT);

- pathogenic microorganisms, in particular bacteria of the Salmonellagenus were studied according to DSTU IDF 122C:2003.

\section{Research results}

6.1. Rationale for the choosing of raw materials for the manufacture of blancmange. For the design of recipes deterministic standard was used, which is entered into the database and it included the norms of physiological needs of the human organism for carbohydrates and proteins. For selected types of nutrients in the process of modeling and assessing the balance of virtual recipes as criteria of food adequacy customized and general indicators of desirability were used. The module, which implemented the evaluation algorithm, at this stage of development functioned without calling the subroutine for calculating the integrated criterion of food adequacy.

When designing Blancmange recipes «Fruit Breeze» and «Protein Breeze» it was necessary to achieve the goal - the maximum value of the product. In the Tables 1,2 data matrix and a range of variation of recipe ingredients (RI) for the design of blancmange recipes «Fruit Breeze» and «Protein Breeze» is presented.

The target function in the design of the recipe composition of blancmange «Protein Breeze» is:

$$
F(x)=\left(\begin{array}{l}
85.3 \cdot x_{1}+72.2 \cdot x_{2}+49.5 \cdot x_{3}+ \\
+81.54 \cdot x_{4}+9.3 \cdot x_{5}+89.5 \cdot x_{6}+ \\
+21.06 \cdot x_{7}+65.51 \cdot x_{8}+99.9 \cdot x_{9}+ \\
+14.6 \cdot x_{10}+87.8 \cdot x_{11}+70 \cdot x_{12}
\end{array}\right) / 250 \rightarrow \max .
$$

On the basis of the information matrix of data (Table 1) let's form a system of linear balance equations for the content in the recipe of macronutrients, in accordance with the following restrictions:

Protein content is not less than 3 , not more than 10 :

$$
F(x)=\left(\begin{array}{l}
85.3 \cdot x_{1}+72.2 \cdot x_{2}+49.5 \cdot x_{3}+ \\
+81.54 \cdot x_{4}+9.3 \cdot x_{5}+89.5 \cdot x_{6}+ \\
+21.06 \cdot x_{7}+65.51 \cdot x_{8}+99.9 \cdot x_{9}+ \\
+14.6 \cdot x_{10}+87.8 \cdot x_{11}+70 \cdot x_{12}
\end{array}\right) / 250 \rightarrow \max .
$$

Fat content $(F)$ is not less than 2, not more than 5 :

$$
\begin{aligned}
& 2 \leq 53.7 \cdot x_{1}+0.5 \cdot x_{2}+15 \cdot x_{3}+35.49 \cdot x_{4}+ \\
& +0.6 \cdot x_{5}+48.5 \cdot x_{6}+1.8 \cdot x_{7}+0.01 \cdot x_{8}+ \\
& +0.4 \cdot x_{10}+0.1 \cdot x_{11} \leq 5
\end{aligned}
$$

Table 1

Information data matrix for designing blancmange recipes

\begin{tabular}{|c|c|c|c|}
\hline Recipe ingredients & Index, $x_{i}$ & $\begin{array}{c}\text { Dry matter } \\
\text { content } \mathrm{RI}, \%\end{array}$ & $\begin{array}{c}\text { Possible range } \\
\text { of variation RI, g/portion }\end{array}$ \\
\hline Almond & $x_{1}$ & 33.8 & $35-45$ \\
\hline Dates & $x_{2}$ & 24.5 & $12-20$ \\
\hline Cocoa powder & $x_{3}$ & 90.8 & $12-20$ \\
\hline Shredded coconut & $x_{4}$ & 74.6 & $35-45$ \\
\hline Blueberries & $x_{5}$ & 26.3 & $25-35$ \\
\hline Cashew & $x_{6}$ & 65.8 & $50-60$ \\
\hline Soy yogurt & $x_{7}$ & 25.3 & $50-60$ \\
\hline Artichoke syrup & $x_{8}$ & 19.3 & $12-20$ \\
\hline Coconut oil & $x_{9}$ & 21.5 & $12-20$ \\
\hline Fresh mango & $x_{10}$ & 18.9 & $40-50$ \\
\hline Vanillin & $x_{11}$ & 87.8 & $4-6$ \\
\hline Collagen hydrolyzate & $x_{12}$ & 94 & $5-10$ \\
\hline
\end{tabular}


The nutritional value of blancmange recipe ingredients

\begin{tabular}{|c|c|c|c|c|c|c|c|c|c|c|c|c|}
\hline Nutrients & Almond & Dates & $\begin{array}{l}\text { Cocoa } \\
\text { powder }\end{array}$ & $\begin{array}{c}\text { Shredded } \\
\text { coconut }\end{array}$ & $\begin{array}{c}\text { Blueber- } \\
\text { ries }\end{array}$ & Cashew & $\begin{array}{c}\text { Soy } \\
\text { yogurt }\end{array}$ & $\begin{array}{l}\text { Artichoke } \\
\text { syrup }\end{array}$ & $\begin{array}{c}\text { Coconut } \\
\text { oil }\end{array}$ & $\begin{array}{l}\text { Fresh } \\
\text { mango }\end{array}$ & Vanillin & $\begin{array}{c}\text { Collagen } \\
\text { hydrolyzate }\end{array}$ \\
\hline \multicolumn{13}{|c|}{ Macronutrients, g/100 g } \\
\hline Pratein & 18.6 & 2.5 & 24.3 & 2.88 & 1.1 & 18.5 & 3.5 & 2 & 0 & 0.8 & 0.1 & 70 \\
\hline Fat & 53.7 & 0.5 & 15 & 35.49 & 0.6 & 48.5 & 1.8 & 0.01 & 0 & 0.4 & 0.1 & 0 \\
\hline Carbohydrates & 13 & 69.2 & 10.2 & 43.17 & 7.6 & 22.5 & 15.76 & 63.5 & 99.9 & 13.4 & 87.6 & 0 \\
\hline Total & 85.3 & 72.2 & 49.5 & 81.54 & 9.3 & 89.5 & 21.06 & 65.51 & 99.9 & 14.6 & 87.8 & 70 \\
\hline \multicolumn{13}{|c|}{ Micronutrients, g/100 g } \\
\hline$\omega_{3}$ & 0.006 & 0.003 & 0 & 0 & 0.058 & 0.161 & 0 & 0 & 0.1 & 0.051 & 0.058 & 0 \\
\hline$\omega_{6}$ & 12.05 & 0.016 & 9 & 0 & 0.088 & 7.66 & 0 & 0 & 1.7 & 0.019 & 0.088 & 0 \\
\hline Vitamin $\Gamma$ & 1.5 & 0.3 & 0 & 0.7 & 10 & 0.5 & 2.5 & 0 & 0 & 36.4 & 0 & 0 \\
\hline Anthocyanins & 0 & 0.137 & 0 & 0 & 0 & 0 & 0 & 0 & 0.237 & 0 & 0.556 & 0 \\
\hline Flavonoids & 0 & 0.247 & 0 & 0 & 0 & 0.02 & 0 & 0 & 0 & 0 & 0.586 & 0 \\
\hline
\end{tabular}

The content of carbohydrates $(C)$ is not less than 10 , not more than 15 :

$$
\begin{aligned}
& 10 \leq 13 \cdot x_{1}+69.2 \cdot x_{2}+10.2 \cdot x_{3}+43.17 \cdot x_{4}+ \\
& +7.6 \cdot x_{5}+22.5 \cdot x_{6}+15.76 \cdot x_{7}+63.5 \cdot x_{8}+ \\
& +99.9 \cdot x_{9}+13.4 \cdot x_{10}+87.6 \cdot x_{11} \leq 15 .
\end{aligned}
$$

Content $\omega_{3}$ is not less than $200 \mathrm{mg}$ :

$0.006 \cdot x_{1}+0.003 \cdot x_{2}+0.058 \cdot x_{5}+0.161 \cdot x_{6}+$

$+0.1 \cdot x_{9}+0.051 \cdot x_{10}+0.058 \cdot x_{11} \leq 200$.

Content $\omega_{6}$ is not less than $600 \mathrm{mg}$ :

$$
\begin{aligned}
& 12.059 \cdot x_{1}+0.016 \cdot x_{2}+9 \cdot x_{3}+ \\
& +0.088 \cdot x_{5}+7.66 \cdot x_{6}+1.7 \cdot x_{9}+ \\
& +0.019 \cdot x_{10}+0.088 \cdot x_{11} \geq 600 .
\end{aligned}
$$

The ratio:

$$
0.2 \leq \frac{\omega_{3}}{\omega_{6}} \leq 1.5 .
$$

The ratio of fat to carbohydrates (mono carbohydrates and starch) is not more than 4 , not less than 2 :

$$
2 \leq \frac{F}{C} \leq 4 \text {. }
$$

Vitamin C content is not less than $14 \mathrm{mg} / 100 \mathrm{~g}$ (20\% of daily requirement):

$$
\begin{aligned}
& 1.5 \cdot x_{1}+0.3 \cdot x_{2}+0.7 \cdot x_{4}+10 \cdot x_{5}+ \\
& +0.5 \cdot x_{6}+2.5 \cdot x_{7}+36.4 \cdot x_{10} \geq 14 .
\end{aligned}
$$

Anthocyanin content is not less than $5 \mathrm{mg} / 100 \mathrm{~g}$ (10\% of daily requirement):

$$
0.137 \cdot x_{2}+0.237 \cdot x_{9}+0.556 \cdot x_{11} \geq 5 \text {. }
$$

The content of flavonoid compounds is not less than $1 \mathrm{mg} / 100 \mathrm{~g}$ :

$0.247 \cdot x_{2}+0.02 \cdot x_{6}+0.586 \cdot x_{11} \geq 1$.
Limitations on collagen hydrolyzate (is not less than $2 \%$, but not more than $5 \%$ ):

$2 \leq x_{11} \leq 5$.

Rationing conditions (yield per $250 \mathrm{~g}$ ):

$x_{1}+x_{2}+x_{3}+x_{4}+x_{5}+x_{6}+x_{7}+x_{8}+x_{9}+x_{10}+x_{11}+x_{12}=250$.

Lower RI limits:

$$
\begin{array}{lll}
x_{1} \geq 35 ; & x_{2} \geq 12 ; \quad x_{3} \geq 12 ; & x_{4} \geq 35 ; \\
x_{5} \geq 25 ; & x_{6} \geq 50 ; \quad x_{7} \geq 50 ; & x_{8} \geq 12 ; \\
x_{9} \geq 12 ; & x_{10} \geq 40 ; \quad x_{11} \geq 4 ; & x_{12} \geq 5 .
\end{array}
$$

Upper RI limits:

$$
\begin{array}{llll}
x_{1} \leq 45 ; & x_{2} \leq 20 ; & x_{3} \leq 20 ; & x_{4} \leq 45 ; \\
x_{5} \leq 35 ; & x_{6} \leq 60 ; & x_{7} \leq 60 ; & x_{8} \leq 20 ; \\
x_{9} \leq 20 ; & x_{10} \leq 50 ; & x_{11} \leq 6 ; & x_{12} \leq 10 .
\end{array}
$$

Similarly, a mathematical model was made to design a prescription composition for «Fruit Breeze» blancmange.

As a result of calculation of the program the shares of prescription components were received:

- for Blancmange «Protein Breeze»:

$$
\begin{aligned}
& x_{1}=38 ; \quad x_{2}=12 ; \quad x_{3}=12 ; \quad x_{4}=35 ; \\
& x_{5}=25 ; \quad x_{6}=35 ; \quad x_{7}=35 ; \quad x_{8}=12 ; \\
& x_{9}=35 ; \quad x_{10}=5 ; \quad x_{11}=4 ; \quad x_{12}=2 \text {. }
\end{aligned}
$$

In this case, $F(x)=65.78$;

- for the «Fruit Breeze» blancmange:

$$
\begin{aligned}
& x_{1}=38 ; \quad x_{2}=12 ; \quad x_{3}=12 ; \quad x_{4}=32 ; \\
& x_{5}=25 ; \quad x_{6}=35 ; \quad x_{7}=35 ; \quad x_{8}=12 ; \\
& x_{9}=32 ; \quad x_{10}=5 ; \quad x_{11}=12 \text {. }
\end{aligned}
$$

In this case, $F(x)=65.78$. 
Thus, the content of basic macronutrients in a portion of «Fruit Breeze» blancmange is $63.24 \mathrm{~g} /$ portion, in a portion of «Protein Breeze» blancmange - $65.78 \mathrm{~g} /$ portion.

According to the results of mathematical design blancmange formulations were received (Table 3).

Table 3

Recipe and utilization rate of raw materials for the production of a portion of blancmange

\begin{tabular}{|c|c|c|c|c|c|c|c|c|}
\hline \multirow{3}{*}{ Raw material } & \multicolumn{4}{|c|}{ «Protein Breeze» } & \multicolumn{4}{|c|}{ «Fruit Вreeze» } \\
\hline & \multirow{2}{*}{$\begin{array}{c}\text { Gross, } \\
\text { g }\end{array}$} & \multicolumn{2}{|c|}{ Waste } & \multirow{2}{*}{$\begin{array}{c}\text { Net, }^{2} \\
\text { g }\end{array}$} & \multirow{2}{*}{$\begin{array}{c}\text { Gross, } \\
g\end{array}$} & \multicolumn{2}{|c|}{ Waste } & \multirow{2}{*}{$\begin{array}{c}\text { Net, } \\
\mathrm{g}\end{array}$} \\
\hline & & $\%$ & g & & & $\%$ & g & \\
\hline Almond & 40 & 5 & 2 & 38 & 40 & 5 & 2 & 38 \\
\hline Dates & 17 & 29 & 5 & 12 & 17 & 29 & 5 & 12 \\
\hline Cocoa powder & 12 & 0 & 0 & 12 & 12 & 0 & 0 & 12 \\
\hline Shredded coconut & 32 & 0 & 0 & 32 & 32 & 0 & 0 & 32 \\
\hline Blueberries & 25 & 0 & 0 & 25 & 25 & 0 & 0 & 25 \\
\hline Cashew & 35 & 0 & 0 & 35 & 35 & 0 & 0 & 35 \\
\hline Soy yogurt & 35 & 0 & 0 & 35 & 35 & 0 & 0 & 35 \\
\hline Artichoke syrup & 12 & 0 & 0 & 12 & 12 & 0 & 0 & 12 \\
\hline Coconut oil & 45 & 29 & 13 & 33 & 45 & 29 & 13 & 32 \\
\hline Fresh mango & 5 & 0 & 0 & 5 & 5 & 0 & 0 & 5 \\
\hline Vanillin & $6 / 15$ & 0 & 0 & $6 / 15$ & 12 & 0 & 0 & 12 \\
\hline Collagen hydrolyzate & 5 & 0 & 0 & 5 & 0 & 0 & 0 & 0 \\
\hline Total & 269 & 63 & 20 & 250 & 270 & 63 & 20 & 250 \\
\hline
\end{tabular}

6.2. Determination of sensory parameters of the finished product. The sensory evaluation was performed by a tasting commission, which consisted of a total of 15 people, immediately after making blancmange.

Evaluation of sensory parameters of the obtained products is given in Table 4.

Table 4

Sensory indicators of developed blancmange

\begin{tabular}{|c|c|c|}
\hline Indicator & «Fruit Вгеeze» & «Protein Вгеeze» \\
\hline Аppearance & $\begin{array}{l}\text { The shape of the sphere, } \\
\text { smooth surface, without de- } \\
\text { formations and tears, the des- } \\
\text { sert has the appropriate size, } \\
\text { attractive appearance }\end{array}$ & $\begin{array}{l}\text { Sphere shape, smooth surface, } \\
\text { slightly porous in section, with- } \\
\text { out deformations and tears, at- } \\
\text { tractive appearance }\end{array}$ \\
\hline Structure & Сreamy, uniform, porous & Creamy, even, porous and gentle \\
\hline Consistence & $\begin{array}{l}\text { Elastic, gelatin form, slightly } \\
\text { porous in section and evenly } \\
\text { distributed pieces of blueber- } \\
\text { ries throughout the volume, } \\
\text { tender }\end{array}$ & $\begin{array}{l}\text { Elastic, gelatin form, slightly } \\
\text { porous in cross-section and } \\
\text { evenly distributed throughout } \\
\text { the volume. Slices of berries } \\
\text { are evenly distributed through- } \\
\text { out the volume (impregnation), } \\
\text { tender }\end{array}$ \\
\hline Taste & $\begin{array}{l}\text { Sweet, creamy, without extra- } \\
\text { neous flavors }\end{array}$ & $\begin{array}{l}\text { Sweet, creamy, without extrane- } \\
\text { ous flavors }\end{array}$ \\
\hline Flavor & $\begin{array}{l}\text { Pure, coconut with a subtle } \\
\text { smell of blueberries and nuts. } \\
\text { Pleasant, pronounced, without } \\
\text { impurities }\end{array}$ & $\begin{array}{l}\text { Pure, coconut with a subtle } \\
\text { smell of blueberries and nuts. } \\
\text { Pleasant, pronounced, without } \\
\text { impurities }\end{array}$ \\
\hline Color & $\begin{array}{l}\text { Light purple, with dark purple } \\
\text { specks }\end{array}$ & $\begin{array}{l}\text { Light purple, with dark purple } \\
\text { specks }\end{array}$ \\
\hline
\end{tabular}

The dynamics of changes in sensory parameters in the scoring system is shown in Fig. 1, 2. The intervals of changes in the values of sensory parameters were assigned equal from 0 to 5 points: $0-1$ - very poor quality; $1-2-$ poor quality; $2-3$ - average quality; $3-4$ - good quality; 4-5 excellent quality.
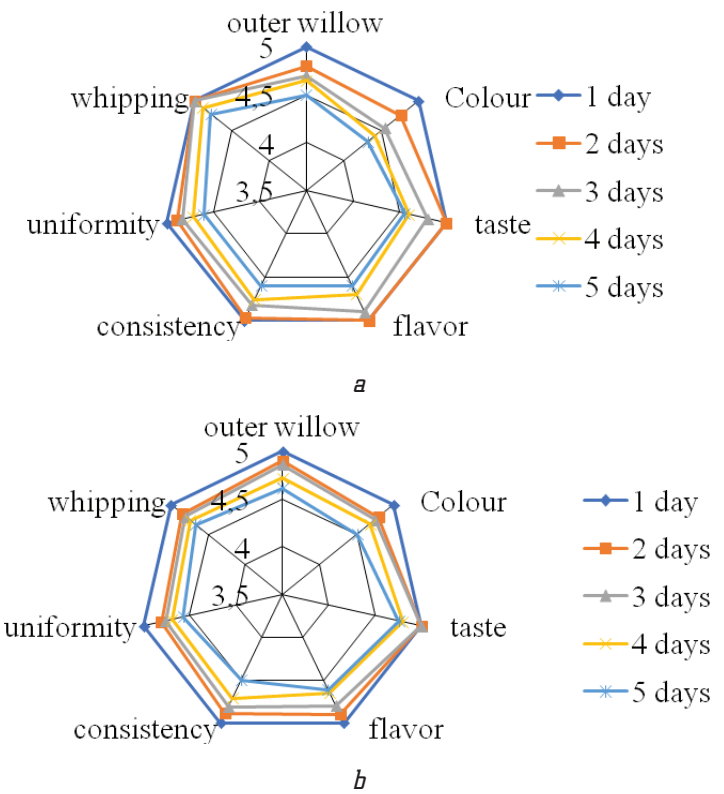

Fig. 1. Dynamics of changes in the sensory parameters of blancmange during storage in glass containers: $a-$ "Protein Breeze»; $b-«$ Fruit Breeze»
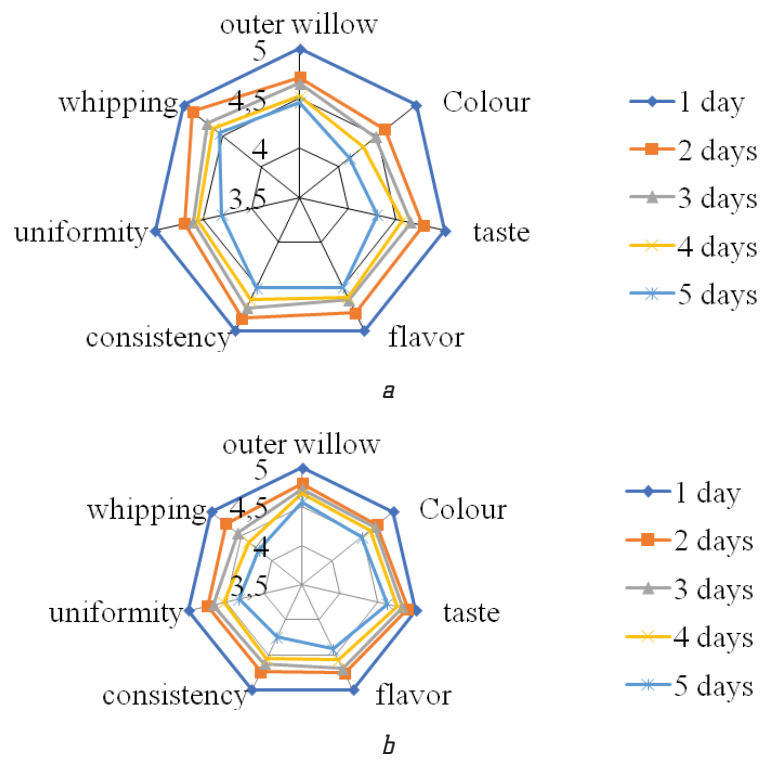

Fig. 2. Dynamics of changes in the sensory parameters of blancmange during storage in polypropylene containers: $a-$ «Protein Breeze»; $b-«$ Fruit Breeze»

From the obtained data it is seen that when stored in a glass container, the sensory parameters change slightly compared to the blancmange, which was stored in a polypropylene container. Therefore, for storage of this type of desserts it is possible to use both glass containers and polypropylene packaging.

6.3. Analysis of nutritional and energy value, antioxidant activity of developed blancmange. It should be noted that 
the developed products have a high content of all essential micronutrients necessary for the human organism namely calcium, phosphorus and potassium, because the production in the recipe uses raw materials with a high content of trace elements such as $\mathrm{Ca}, \mathrm{K}$ and $\mathrm{R}$. The degree of daily needs human in the main vitamins, \% when consuming one serving of blancmange is presented in (Table 5).

The degree of satisfaction of the daily human demand for essential vitamins, \% (when consuming a portion of blancmange)

\begin{tabular}{|c|c|c|c|c|c|}
\hline \multirow{2}{*}{$\begin{array}{c}\text { Micronutri- } \\
\text { ents }\end{array}$} & $\begin{array}{c}\text { Daily } \\
\text { demand, } \\
\text { mg }\end{array}$ & $\begin{array}{c}\text { «Protein Breeze» } \\
\text { a portion, } \\
250 \text { g }\end{array}$ & $\begin{array}{c}\text { satisfac- } \\
\text { tion of } \\
\text { daily de- } \\
\text { mand, \% }\end{array}$ & $\begin{array}{c}\text { «Fruit Breeze» } \\
\text { a portion, } \\
250 \text { g }\end{array}$ & $\begin{array}{c}\text { satisfac- } \\
\text { tion of } \\
\text { daily de- } \\
\text { mand, \% }\end{array}$ \\
\hline $\mathrm{A}$ & 0.1 & 0.02 & 21.24 & 0.02 & 19.86 \\
\hline$\beta$-carotene & 6 & 0.02 & 0.34 & 0.02 & 0.34 \\
\hline $\mathrm{B}_{1}$ & 1.5 & 0.19 & 12.35 & 0.18 & 12.28 \\
\hline $\mathrm{B}_{2}$ & 1.8 & 0.12 & 6.76 & 0.12 & 6.75 \\
\hline $\mathrm{B}_{5}$ & 2 & 0.93 & 46.31 & 0.91 & 45.43 \\
\hline $\mathrm{B}_{6}$ & 0.6 & 0.33 & 54.93 & 0.33 & 54.27 \\
\hline $\mathrm{Bg}$ & 0.2 & 0.06 & 29.92 & 0.06 & 29.52 \\
\hline $\mathrm{E}$ & 15 & 11.41 & 76.06 & 11.49 & 76.62 \\
\hline $\mathrm{PP}$ & 20 & 5.62 & 28.12 & 5.62 & 28.11 \\
\hline $\mathrm{C}$ & 80 & 14.99 & 18.74 & 14.68 & 18.35 \\
\hline $\mathrm{Na}$ & 400 & 117.74 & 29.44 & 110.33 & 27.58 \\
\hline $\mathrm{Ca}$ & 300 & 189.93 & 63.31 & 190.43 & 63.48 \\
\hline $\mathrm{Mg}$ & 400 & 250.94 & 62.74 & 249.62 & 62.41 \\
\hline $\mathrm{S}$ & 1000 & 119.51 & 11.95 & 119.86 & 11.99 \\
\hline $\mathrm{P}$ & 400 & 372.97 & 93.24 & 370.38 & 92.60 \\
\hline $\mathrm{Cl}$ & 2000 & 22.31 & 1.12 & 22.94 & 1.15 \\
\hline $\mathrm{Fe}$ & 18 & 6.50 & 36.10 & 6.49 & 36.06 \\
\hline $\mathrm{K}$ & 2500 & 843.21 & 33.73 & 832.14 & 33.29 \\
\hline
\end{tabular}

Because blancmange contains protein, an analysis of the amino acid composition was performed. Studies have shown that the protein component contains nineteen amino acids, all of which are essential.

The daily demand of the human organism for essential amino acids due to the consumption of a portion of blancmange is presented in Table 6. Consumption of one portion of Blancmange «Protein Breeze» will provide the human organism with essential amino acids in total by almost $106 \%$, and Blancmange «Fruit Breeze»-58.6\%.

Studies of the biological value of blancmange were studied by calculating the amino-acid score, which is given in Table 7 .

The biological value of proteins is determined not only by their amino acid composition, but also the degree of digestibility. The intensity of the process of protein breakdown in the human digestive tract depends on the activity of proteolytic enzymes and the biological form of the protein components of the product.

According to the research results, the degree of digestibility of the developed desserts «Protein Breeze» and «Fruit Breeze» was 84.5 and $82.1 \%$, respectively.
Table 6

The degree of satisfaction of the daily demand for essential amino acids, \% (when consuming a portion of blancmange)

\begin{tabular}{|c|c|c|c|c|c|}
\hline \multirow{2}{*}{ Amino acids } & \multirow{2}{*}{$\begin{array}{c}\text { Daily } \\
\text { demand, } \\
\text { mg }\end{array}$} & $\begin{array}{c}\text { «Protein Breeze» } \\
\text { in } \\
\text { a portion, } \\
250 \text { g }\end{array}$ & $\begin{array}{c}\text { satisfac- } \\
\text { tion of } \\
\text { daily de- } \\
\text { mand, \% }\end{array}$ & $\begin{array}{c}\text { «Fruit Breeze» } \\
\text { a portion, } \\
250 \text { g }\end{array}$ & $\begin{array}{c}\text { satisfac- } \\
\text { tion of } \\
\text { daily de- } \\
\text { mand, \% }\end{array}$ \\
\hline Arginine & 5 & 4.0 & 80.7 & 2.3 & 46.1 \\
\hline Valine & 0.8 & 2.1 & 264.2 & 1.3 & 168.3 \\
\hline Histidine & 2 & 0.7 & 35.1 & 0.5 & 27.1 \\
\hline Isoleucine & 0.7 & 1.4 & 207.0 & 0.9 & 133.2 \\
\hline Leucine & 1.1 & 2.7 & 242.7 & 1.7 & 150.8 \\
\hline Lysine & 0.8 & 2.0 & 250.9 & 1.0 & 127.4 \\
\hline Methionine & 1.1 & 0.6 & 53.7 & 0.4 & 39.2 \\
\hline Cysteine & 3 & 0.3 & 11.5 & 0.3 & 11.5 \\
\hline Threonine & 0.5 & 1.5 & 307.4 & 0.8 & 165.2 \\
\hline Tryptophan & 0.25 & 0.3 & 117.8 & 0.3 & 117.8 \\
\hline Phenylalanine & 1.1 & 1.7 & 154.5 & 1.2 & 109.2 \\
\hline
\end{tabular}

Table 7

Determination of amino-acid score in the developed blancmange

\begin{tabular}{|c|c|c|c|c|c|}
\hline \multirow[b]{2}{*}{$\begin{array}{c}\text { Essential } \\
\text { amino acid }\end{array}$} & \multirow{2}{*}{$\begin{array}{c}\text { The content of } \\
\text { essential amino } \\
\text { acids in the } \\
\text { ideal protein, } \\
\mathrm{mg} / \mathrm{g} \cdot \mathrm{P}\end{array}$} & \multicolumn{2}{|c|}{ «Protein Вreeze» } & \multicolumn{2}{|c|}{ «Fruit Вreeze» } \\
\hline & & $\mathrm{mg} / \mathrm{g} \cdot \mathrm{P}$ & $\begin{array}{c}\text { amino- } \\
\text { acid } \\
\text { scare, \% }\end{array}$ & $\mathrm{mg} / \mathrm{g} \cdot \mathrm{P}$ & $\begin{array}{l}\text { amino- } \\
\text { acid } \\
\text { score, \% }\end{array}$ \\
\hline Isoleucine & 40 & 74.0 & 185.10 & 47.6 & 119.08 \\
\hline Leucine & 70 & 136.4 & 194.89 & 84.8 & 121.10 \\
\hline Lysine & 55 & 102.6 & 186.51 & 52.1 & 94.723 \\
\hline Methionine & 35 & 30.2 & 86.17 & 22.0 & 62.87 \\
\hline Phenylalanine & 60 & 86.8 & 144.73 & 61.4 & 102.33 \\
\hline Threonine & 40 & 78.5 & 196.32 & 42.2 & 105.54 \\
\hline Tryptophan & 10 & 15.1 & 150.52 & 15.1 & 150.52 \\
\hline Valine & 50 & 108.0 & 216.03 & 68.8 & 137.58 \\
\hline Total & 360 & 631.65 & - & 393.98 & - \\
\hline
\end{tabular}

Also, as a part of the study, the qualitative and quantitative composition of the microbiota developed blancmange during their storage for 5 days in glass and polypropylene containers at a relative humidity of $75-85 \%$ and a temperature of $4 \pm 2{ }^{\circ} \mathrm{C}$ was determined. Establishment of safe shelf-life was performed in the presence of sanitaryindicatory microorganisms. To study microbiological parameters during storage (for 5 days) determined the presence and amount of MAFAnM - according to GOST 10444.15, pathogenic bacteria, including Escherichia coli - according to GOST 30726-2001, yeast and molds - according to GOST 10444.12.

On the basis of the received data of definition of change of sensory and microbiological indicators at storage of the developed blancmange it is possible to state that at observance of the recommended conditions, products have rather high indicators of quality (Fig. 1,2). Thus, when stored for 5 days, the total score on sensory indicators is reduced to 31.7 points for «Protein Breeze» and 29.5 points 
for «Fruit Breeze» from 35 possible points in accordance with the microbiological indicators of SanPiN 2.3.4.551-96. Thus, the following storage conditions can be recommended: for 5 days in glass containers or polypropylene packaging at a temperature of $(4 \pm 2){ }^{\circ} \mathrm{C}$ and relative humidity not exceeding $75 \%$.

\section{SWOT analysis of research results}

Strengths. The strengths of this research are the development of blancmange recipes with a balanced nutrient composition using vegetable raw materials.

Weaknesses. The weak side of the research is the almond content, which can cause an allergic reaction. Also, the presence of fat-containing raw materials (coconut oil and cashews) significantly increases the energy value of the product, which narrows the range of consumers developed blancmange.

Opportunities. The resulting blancmange can be recommended for use by people with hypolactasia. Developed desserts can be included in the diet in the field of HoReCa: dining outlets, hospitality industry and children's nutrition.

Threats. For the introduction of the developed blancmange into production, it is planned to conduct a SWOTanalysis of the technology for obtaining these desserts, to develop prerequisite programs for the developed technology in accordance with international HACCP safety standards.

\section{Conclusions}

1. Blancmange recipes using non-traditional raw materials have been developed. Due to the use of vegetable milk, blancmange compositions were obtained, which can be used for the production of dessert products for people suffering from hypolactasia. The recipes were optimized using the Solver spreadsheet (MS Excel 2010), the optimal content of all components was set.

2. On the basis of the conducted microbiological researches it is established that at storage of the developed blancmange in regulated conditions, these products have rather quite good quantitative and qualitative indicators (Fig. 1, 2). The recommended shelf-life is 5 days at air temperature $(4 \pm 2)^{\circ} \mathrm{C}$ and relative humidity not more than $75 \%$ in glass or polypropylene containers.

3. Consumption of $100 \mathrm{~g}$ of developed blancmange «Fruit Breeze» and «Protein Breeze» will provide the human organism with $63.24 \mathrm{~g}$ and $65.78 \mathrm{~g}$ of macronutrients, respectively. Consumption of a portion of developed blancmange will meet the average requirements of the organism in $\mathrm{B}$ vitamins by almost $40 \%$. The ratio of calcium, magnesium and phosphorus is equal to blancmange «Fruit Breeze» 0.98:1:1.48, and blancmange «Protein Breeze» 1.01:1:1.49, which corresponds to the recommendations of nutrition.

\section{References}

1. Kushnir, N. A., Telezhenko, L. M. (2012). Pat. No. 79357 UA. Sposib oderzhannia kolahenovoho preparatu. MPK: A23J 1/04 (2006.01). No. u201209751; declareted: 13.08.2012.; published: 25.04.2013, Bul. No. 8/2013.
2. Fasoli, E., D’Amato, A., Kravchuk, A. V., Citterio, A., Righetti, P. G. (2011). In-depth proteomic analysis of non-alcoholic beverages with peptide ligand libraries. I: Almond milk and orgeat syrup. Journal of Proteomics, 74 (7), 1080-1090. doi: http:// doi.org/10.1016/j.jprot.2011.03.016

3. Swagerty, D. L. Jr., Walling, A. D., Klein, R. M. (2002). Lactose intolerance. American Family Physician, 65, 1845-1850.

4. Norouzi, S., Pourjafar, H., Ansari, F., Homayouni, A. (2019). A Survey on the survival of Lactobacillus paracasei in fermented and non-fermented frozen soy dessert. Biocatalysis and Agricultural Biotechnology, 21, 101297. doi: http://doi.org/ 10.1016/j.bcab.2019.101297

5. Protte, K., Weiss, J., Hinrichs, J., Knaapila, A. (2019). Thermally stabilised whey protein-pectin complexes modulate the thermodynamic incompatibility in hydrocolloid matrixes: A feasibility-study on sensory and rheological characteristics in dairy desserts. $L W T, 105,336-343$. doi: http://doi.org/10.1016/ j.lwt.2019.01.047

6. Suebsaen, K., Suksatit, B., Kanha, N., Laokuldilok, T. (2019). Instrumental characterization of banana dessert gels for the elderly with dysphagia. Food Bioscience, 32, 100477. doi: http:// doi.org/10.1016/j.fbio.2019.100477

7. Nunes, M. C., Batista, P., Raymundo, A., Malvesm, M. M., Sousa, I. (2003). Vegetable proteins and milk puddings. Colloids and Surfaces B: Biointerfaces, 31 (1-4), 21-29. doi: http:// doi.org/10.1016/s0927-7765(03)00040-7

8. Putrina, A. E., Sycheva, O. V. (2015). Innovatsionnii desert blanmanzhe molochnoe. Sovremennye dostizheniia biotekhnologii. Aktualnye problemy molochnogo dela. Severo-Kavkazskii federalnii universitet, 331-333.

9. Tsykhanovska, I., Yevlash, V., Alexandrov, A., Khamitova, B., Svidlo, K., Nechuiviter, O. (2019). Forming the structure of whipped desserts when introducing the food additive «Magnetofood» to their formulation. Eastern-European Journal of Enterprise Technologies, 2 (11 (98)), 45-55. doi: http://doi.org/ 10.15587/1729-4061.2019.161855

10. Kim, Y. J., Kang, S., Kim, D. H., Kim, Y. J., Kim, W. R., Kim, Y. M., Park, S. (2017). Calorie reduction of chocolate ganache through substitution of whipped cream. Journal of Ethnic Foods, 4 (1), 51-57. doi: http://doi.org/10.1016/j.jef.2017.02.002

11. O'Chiu, E., Vardhanabhuti, B. (2017). Utilizing whey protein isolate and polysaccharide complexes to stabilize aerated dairy gels. Journal of Dairy Science, 100 (5), 3404-3412. doi: http:// doi.org/10.3168/jds.2016-12053

12. Dziuba, N. A. (2019). Kompozytsiine proektuvannia polikomponentnykh musiv bioprotektornoi dii. Vcheni zapysky Tavriiskoho natsionalnoho universytetu im. V. I. Vernadskoho. Seriia Tekhnichni nauky, 30 (69), 86-92.

Dzyuba Nadya, PhD, AssociateProfessor, Department of Restaurant and Health Food Technology, Odessa National Academy of Food Technologies, Odesa, Ukraine, e-mail: dzyubanadya282@gmail.com, ORCID: http://orcid.org/0000-0001-6609-3965

Bunyak Elena, Postgraduate Student, Department of the Grain Processing Technology, Odessa National Academy of Food Technologies, Odesa, Ukraine, e-mail: bunyak.e.v@gmail.com, ORCID: http:// orcid.org/0000-0003-2643-1223

Telezhenko Liubov, Doctor of Technical Sciences, Professor, Department of Restaurant and Health Food Technology, Odessa National Academy of Food Technologies, Odesa, Ukraine, e-mail: telegenko@ukr.net, ORCID: http://orcid.org/0000-0001-6675-2625

Oliinyk Mariia, Postgraduate Student, Department of Restaurant and Health Food Technology, Odessa National Academy of Food Technologies, Odesa, Ukraine, e-mail: moleynik4@gmail.com, ORCID: http:// orcid.org/0000-0002-1103-2628 